\title{
Urinary lithiasis in civil construction workers as a management indicator for health and improvement in personnel
}

Renato Ribeiro Nogueira Ferraz ${ }^{1}$

Simone Aquino ${ }^{1}$

${ }^{1}$ Programa de Mestrado Profissional em Administração - Gestão em Sistemas de Saúde, Universidade Nove de Julho.

Av. Francisco Matarazzo 612/Prédio $\mathrm{C} / 1^{\circ}$ andar, Barra Funda. 01156-050 São Paulo SP Brasil. renatoferraz@uninove.br

\begin{abstract}
Introduction: Empirical information provided by health care professionals acting in the first line of care report a constant increase in the number of civil construction workers that present painful acute conditions, in most cases associated with the existence of urinary tract calculi. Aims: Evaluating the prevalence of urinary lithiasis in civil construction workers, as a means to identify indicators for the management of health and personnel. Methods: Observational study based on directed questionnaire. Results: From the 94 participants, 18 (19\%) were lithiasic, mostly due to overweight and reduced fluid intake. Conclusion: The observed prevalence appeared to be two times greater than that of the general population. Thus, prevention for such condition gains relevance, in order to avoid discomfort for the worker, and also reduce costs due to absenteeism, improving productivity, benefiting the workers by performance and creating the perspective of an improved quality of life.
\end{abstract}

Key words Health management, Civil construction, Risks, Prevalence. Urinary lithiasis 


\section{Introduction}

Considerable growth can be noticed in the segment of civil construction in Brazil, which accounts for $5 \%$ of the national GDP. Due to strong competition in such market, in the past few years, companies of this segment have developed strategies for planning, production control and quality of services ${ }^{1}$. The industry of civil construction has a wide range of workers linked to buildings of great structures such as corporate constructions, hydroelectric plants, bridges, viaducts, underground stations and towers for telecommunications. Given that in the sector of civil construction the likelihood of a worker suffering an accident, becoming ill or even dying is relevant, identifying the main risks of such becomes yet more important. These risks may vary depending to the insertion of the worker in different work processes $^{2}$. One could also highlight that, according to Brant and Minayo-Gomes ${ }^{3}$ : "health and illness cannot be defined only by the lack or presence of certain etiologic agents and symptoms and that the process health-illness cannot be reduced to a group of meanings determined by the corporate culture and by the discourse of the hegemonic physician".

The occurrence of work accidents may generate, beyond the highly negative consequences related to the human aspect, economic losses relevant to the company and society, which may become an obstacle to the full development of a nation's economy ${ }^{2}$. Therefore, the knowledge about prevention against the risks to health adopted by the management of personnel enables the worker to develop his functions with motivation and satisfaction, felling valued as a human being, once health is much more than the lack of illness, but it is directly related to the quality of life. Health depends on social, historical, economic and environmental conditions, depending also on choices one makes on a daily basis. According to the World Health Organization (WHO), health must be understood as "a state of complete physical, mental and social well-being and not only the lack of affections and infirmities".

Amongst the main causes of work accidents, one may highlight specially those associated with alcohol abuse $e^{4}$ and other licit and illicit drugs ${ }^{5}$. Particularly regarding alcohol abuse, it is a fact that civil construction companies have been more and more concerned about its consumption onsite. In some cases, not only are the accidents due to its abuse are considered, but also the increase in the incidence of some morbidi- ty conditions directly associated to absenteeism such as, for example, urinary lithiasis ${ }^{6}$. Either way, the knowledge of peculiarities associated to use of licit and illicit drugs, not exclusively related to work place accidents, is essential as a means to subsidise public policies on health concerned with this important theme $e^{7}$.

As mentioned previously, civil construction is currently one of the most important activities within the country, being responsible for 3.5 million jobs in Brazil, which corresponds to $6 \%$ of the total. The vast majority of these workers (circa $81 \%$ ) is composed by individuals coming from the Northeast region of the country, with a low degree of schooling and limited socioeconomic status. Amongst the health problems more commonly observed within this group of workers, one may highlight diseases associated with alcohol consumption, mental and psychosomatic illnesses, apart from the evident work place accident $^{8-10}$. Workers from civil construction have demonstrated a low degree of knowledge with regards to their occupational health, and directed their care almost exclusively towards accident prevention $^{11}$.

The Occupational Health Surveillance (VISAT in Portuguese), defined by the Ministry of Health under the Guideline MS/GM no. $3.120^{12}$ acts in the detection, research and analysis of the determinant and conditioning factors of health related matters associated to work processes and environments, in its technological, social, organizational and epidemiological aspects. This Guideline aims at promoting health for workers through actions that consider planning, execution and evaluation of interventions, in order to eliminate and control raising problems. VISAT is structuring and essential to the model of Integral Health in the Brazilian National Health System (SUS in Portuguese).

The social and epidemiological indicators provide a north to the actions of VISAT, in the interventions based upon the identification of risky situations, vulnerability or impact on the health of workers. Nonetheless, collection of data and indicators was not always easily done. The reasons for under notification of morbimortality of occupational and work-related hindrances may be attributed to problems regarding the definition, identification and the registry of the phoneme itself ${ }^{13}$. In this sense, aspects related to the difficulty in understanding what a risk factor is, its occurrences circumstances and its relation with the work environment would be involved, limiting the occupational nexus in the diagnos- 
tic process. Such situation reflects several factors, including, political, legal, conflicts of economic interest, stigma, neglect from health care professionals and employers and even the workers themselves ${ }^{14}$.

From 2002 onwards, a National Network of Integral Care for Workers Health (RENAST in Portuguese) was created, with the objective of articulating health action for workers in the perspective of intra-segmentation focusing on assistance, surveillance and promotion of health, and aiming at guaranteeing integral health care to workers. Furthermore, it articulates intra-segment actions, establishing relationships with other institutions and public and private bodies, such as universities and research institutes. The actions of RENAST are structured through Workers Health Reference Centres (CEREST in Portuguese), which act at state, region and municipality level. The CERESTs develop preventive actions promote health and assistance, including diagnostic, treatment and physical rehabilitation, apart from the surveillance of work places, human resources formation and workers orientation ${ }^{15}$.

CEREST also welcomes workers possessing work-related conditions sent by SUS or Trade Unions. It promotes educational activities, research / interventions, workshops and permanent education on Workers Health for SUS and society in general, involving Trade Unions, companies, Universities and other training centres. Under this scope, the surveillance actions focused on workers health, through CERETs, may represent a supporting tool for personnel management and entrepreneurs in civil construction.

The formation of "kidney stones" (lithiasis) has become a severe public health problem in current society. The incidence of urinary lithiasis has been growing through out the years, such that one may estimate that about 10 to $15 \%$ of the global population is, currently, affected by urinary tract infection processes ${ }^{16,17}$.

The standard of living and the nutritional conditions have influenced directly the process of formation of urinary calculi within communities around the globe. A low socioeconomic level is associated with the endemic formation of bladder stones, which can be observed in many poor countries, where most of the population is malnourished, meanwhile the incidence of upper urinary tract stones rises with the increase in prosperity and more nutritive diets. The substitution of open surgical techniques for minimally invasive techniques has reduced considerably morbidity and mortality of patients, not to men- tion the reduction of hospitalization time, along the consequent reduction of days missing work, minimizing economic losses overall ${ }^{18}$.

Workers of civil construction remain reasonable periods of time with no postural change, often under high temperatures ${ }^{1,9}$. The existence of pre-determined pauses may bring about a reduced fluid intake with the consequent reduction of the final urinary volume. On the other hand, pre-determined pauses may result in low frequency urination, increasing the risk of oversaturation and crystallization of urine stored in the bladder ${ }^{19,20}$, beyond contributing to the installation of a greater number of urinary tract infections $^{21}$, which may influence by elevating the risk of formation of stones.

It is known that the diet is a factor of extreme importance when attempting to reduce the number of calculi episodes. The care with feeding must have as main focus the reduction of incidence and, particularly, recurrence of urinary lithiasis. Modifications in the diet may be made to avoid the installation of several metabolic disturbances that contribute to the formation of stones. Following a strict diet as a means to maintaining weight within the range of normality might already be considered an important prophylactic manoeuvre against the formation of calculi ${ }^{22}$. The maintenance of water intake of circa 2 litres per day maintains a reasonable flow of urine, which on its own is a preventing factor against urine crystallization ${ }^{23-25}$.

As the majority of civil construction companies pre-determined the times of pauses for workers, the simple action of bringing water to the work position could contribute to the formation of a greater urine volume and, consequently, the reduction in the number of lithiasis cases in this specific population of workers. However, one must highlight that not all fluids are indicated. Black tea and cola-based sodas must be avoided, as they interfere negatively in the urinary biochemistry and predispose crystallization ${ }^{26}$. Natural orange or lemon juice may, apart from elevating the urine volume, raise the urine concentration of citrate, which is an important inhibitor of urinary crystallization ${ }^{27}$. It is already widely known in our society that the regular ingestion of water, with the consequent maintenance of a urinary debt of circa 1.5 litres / day is a protecting factor against the formation of calculi, once it dilutes the urine salts, avoiding aggregation.

Based on the information insofar presented, it becomes the focal point of this research the identification and use of the ratio of prevalence 
of risk factors for the formation of kidney stones among civil construction workers as contributors for the creation of strategies and campaigns focused on prevention, once urinary lithiasis is a clinical condition with direct impact on the elevation of absenteeism rates, especially due to the discomfort and morbidity of such condition. One understands that this information may be used as indicators for preventive actions in the management of people in civil construction.

\section{Aims}

Evaluating the prevalence of urinary lithiasis among civil construction workers, as well as identifying possible risk factors involved in the aetiology of the referred illness, providing data for the formulation of preventive campaigns specifically directed toward this category of professionals.

\section{Methods}

This consists of a cross-sectional descriptive prospective study, using a quantitative approach, for which the data was collected between April and July 2011. The population sample for this research, chosen at random, is composed of civil construction workers acting on several regions of the municipality of São Paulo - SP. In total, 94 individuals were evaluated, all male, with average age of $41 \pm 14$ years of age.

The workers belonged to several construction companies hired by big building sites in which they executed different tasks at the time of the research. The instrument of data collection was composed by a questionnaire of 20 closed questions regarding the presence in those individuals of what could suggest the risk of formation of urinary tract stones. Data regarding work function, gender, age, height and weight (for the calculation of BMI - Body Mass Index) was also collected with the goal of better describing the sample studied.

The questionnaires were answered with no interference from the researchers, with the maximum time of 20 minutes. Any volunteer, aging 18 years or more, that executed manual labour, was willing to fill the questionnaire and would consent in the use of the data by signing a Statement of Informed Consent was included in the sample.

No information that enabled the identification of companies or participants was released in this study. The study was registered in the National Health Board (CNS in Portuguese) and approved by the Committee on Ethics in Research from Universidade Nove de Julho - UNINOVE, for following the guidelines established under Resolution $196 / 96^{28}$ from CNS with regards to ethical and legal matters.

\section{Results}

From the 94 workers, 18 of them (19\% of the sample) reported having had at least one episode of urinary calculi since the beginning of their activities in civil construction. One questionnaire used with these workers resulted in Table 1.

When questioned about the intensity of the urine odour, $28 \%$ reported presence of "strong odour", 39\% stated smelling a "weak odour" whilst urinating and 33\% denied smelling any odour at all.

In the evaluation of the number of pauses to urinate, $11 \%$ reported either eight or ten pauses, $17 \%$ affirmed having paused six times, $22 \%$ stopped five times, $17 \%$ reported four pauses, $5.5 \%$ have paused three times, $11 \%$ stopped twice and $5.5 \%$ reported pausing once. Overall, slightly over half of the respondents informed having urinated between four and six times per day.

With regards to the question on whether they took water to the work place, $39 \%$ of the participants have said not to posses such habit.

Table 1. Answers from the questionnaire used with lithisiac workers.

\begin{tabular}{lr}
\hline 1. Have you observed any odour whilst urinating? & 6 \\
Yes & 13 \\
No & 6 \\
2. If so, how strong was the smell? & 7 \\
Strong & \\
Weak & 1 \\
3. How often did you stop working to urinate? & 2 \\
1 time & 1 \\
2 times & 3 \\
3 times & 4 \\
4 times & 3 \\
5 times & None \\
6 times & 2 \\
7 times & None \\
8 times & 2 \\
9 times & \\
10 times & 11 \\
4 Did you take water to the work place & 7 \\
Yes & \\
No &
\end{tabular}


Due to the restrict access to water at any moment during the working time in the operational field in some civil construction buildings, situation reported informally by uncountable workers of the mentioned field, and also due to the fact that workers are not used to taking water to their own posts, some employees of this industry could, by chance, present a reduced urine volume, urine in dark colour and /or with strong smell, amongst other signs that could suggest an increased predisposition to the formation of urinary tract calculi ${ }^{9}$.

The elevated pointed presence of calculi episodes observed in our sample (19\% of the interviewed, approximately one fifth of the total) is considerably higher than the average of 10\% (between 5 and 15\%) in the population of the world. As main factors contributing to the phenomena presented in this study, one may highlight the elevated BMI and the reduced fluid intake, noted in more than half the individuals reporting kidney colic episodes. Considering this fact, several authors have already reported the existence of an important relationship between an elevated BMI and a higher risk of urinary crystallization with consequent lithogenesis, corroborating the findings of the brief study. Therefore, it becomes strongly evident the influence of elevated body mass index in the also considerably high prevalence of urinary lithiasis identified in the population of this study. In our research, we have

Table 2. Body Mass Index (BMI) of total $(\mathrm{n}=94)$ interviewed workers.

\begin{tabular}{lcc}
\hline \multicolumn{1}{c}{ BMI $^{*}$} & Interpretation & $\begin{array}{c}\text { Number } \\
\text { of workers } \\
(\mathbf{n} / \%)\end{array}$ \\
\hline Between 18,5 \& 24,9 & Normal weight & $54(57 \%)$ \\
Between 25,0 \& 29,9 & Overweight & $28(30 \%)$ \\
Above 30 & Obesity degree I & $12(13 \%)$ \\
\hline
\end{tabular}

Source: Associação Brasileira para o Estudo da Obesidade $(\mathrm{ABESO}, 2013)^{29}$.

noticed that half the lithiasic individuals did not take water to their work post, which might have influenced directly the described elevated prevalence, given that this condition can result in the formation of concentrated urine and consequent increase of the risk of crystallization.

The data presented in this study suggests that civil construction companies observe and create incentive programs to promote hydric ingestion by providing water sources in strategic points, aiming at reducing the number of kidney stone episodes amongst their workers. Furthermore, a nutritional follow-up to reduce BMI based on programs of feeding education could reduce the economic losses and decreases in sanity generated by high absenteeism associated to this clinical condition. These measures, which contribute to the prevention and quality of life of the workers, represent a low investment when compared to the costs of treating lithiasis.

The cost of $500 \mathrm{~mL}$ water bottles in the market varies between $\mathrm{R} \$ 0.79$ and $\mathrm{R} \$ 1.80$. Civil construction companies could provide on a daily basis five $500 \mathrm{~mL}$ bottled waters to workers, considering 2.5 litres of water intake sufficient. Besides, one could recommend workers to stop a greater number of times during work, suggesting that apart from the water intake, the should urinate more often, avoiding urinary statis. The approximated cost would be R $\$ 10.00$ per worker per day. The association of mineral water suppliers could reduce the buying costs in exchange for marketing campaigns in the civil construction area.

Street $^{30}$ and Cook $^{31}$ calculated the expenses with alternative treatments for urinary calculi, including total hospitalization costs (physician, hospital stay, diagnostic procedures, nurses, indirect costs, medication and depreciation) and the expenses for the patient (including travel time and cost and time and cost of travel and stay of relatives). The study of these authors shows that on average the costs of the open surgery, the endoscopic surgery and lithotripsy are US\$ 3,366, US\$2,699 and US\$ 4,617 respectively. Including indirect costs and costs to the patient, the total expense with the treatment rises to US\$ 6,922, US\$ 4,422 and US\$ 5,536 respectively. Thus, based on hospital costs, lithotripsy is the most expensive form of treatment, but when considering patient costs, it falls below the open surgery. The reason being that in open surgery, there is the need for hospitalization for an average period of 15 days after the surgery, whilst the lithotripsy requires rest of about two days in the comfort of the patients home. 
A study of the reimbursement value in the Brazilian National Health System (SUS in Portuguese) for lithotripsy, based on the quantity of impulses for the treatment of lithiasis in Brasilia University Hospital, made by Costa e Silva ${ }^{32}$, detected that SUS reimburses R $\$ 172.00$ for each 700 impulses - within the range of 0 and 2,800 impulses per session, and $\mathrm{R} \$ 150,50$ per $700 \mathrm{im}$ pulses - within the range of 2,801 and $5600 \mathrm{im}$ pulses per session. As the average in the hospital is 3,000 impulses, the mean reimbursement in SUS is R $\$ 752.50$ per session. To this value one must add R\$14.84 in the cases where the patient needs painkillers. Besides, the Ministry of Health, by means of the Incentive Factor to the Development of Teaching a Research in Health (FIDEPS in Portuguese), differentiates be reimbursement in university hospitals, once they incorporate teaching and research activities. Hence, in this research, for each session of lithotripsy a reimbursement of R $\$ 910.53$ was considered, and when painkillers were needed, the value of the session reached $\mathrm{R} \$ 928.48$. The authors also report that the cost of equipping a room in the surgical centre for treatment of urinary calculi was of $\mathrm{R} \$ 345,710.82$, with an estimated useful life of 15 years, resulting in an annual depreciation of $\mathrm{R} \$ 23,047.39$. The equipment in the surgery centre has no residual value. The cost of construction of the surgery room would reach the magnitude of $\mathrm{R} \$ 40,000.00$ (for a room of $40 \mathrm{~m}^{2}$ ) and the estimated useful life is of 25 years, resulting in a depreciation of annual $R \$ 1,600.00$. On its turn, the annual maintenance of such surgery room is estimated to be $\mathrm{R} \$ 11,433.45$. Hence, the basis of the calculations of annual depreciation and nonused installed capacity was $\mathrm{R} \$ 34,480.84$ and $\mathrm{R} \$$ 1,600 , respectively for the year $2006^{32}$. All the above-mentioned costs are far higher than that of providing a mineral water source, or even the increase in number of pauses to urinate, which per se could diminish considerably the incidence of lithiasis in the inhere-described workers.

One should highlight that, in the cases of complaints, notifications or emergence of new indicators that point to the decrease in workers health, beyond epidemiological situations, the oversight of VISAT in the workplace may bring intervention in corporations for actions of evaluation, investigations and monitoring, and possibly fining and suspension of activities, causing operational and financial hiccups. The stimuli for the participation of workplace representatives in official instances in SUS has been growing, as in the intra-segment commissions and boards in the thee spheres of management in SUS, with transparency and easy access to information to community representatives, workers and social $\operatorname{control}^{33}$. On the other hand, workers health surveillance actions, through CERESTs, may represent a tool to support the management of people and entrepreneurs in civil construction, once the capacitation and in-company workshops (about promoting health for workers) are pillars of the actions of VISAT, in partnership with private segments, establishing the adoption of parameters to protect the health of workers in the work environment and processes ${ }^{33}$. Such partnership in capacitation of workers should be the focus of managers in civil construction in the orientation and education of employees, as a means to minimize the risks of urinary lithiasis in their payroll.

\section{Conclusion}

The prevalence of urinary lithiasis amongst Brazilian civil construction workers was nearly twice as big as that observed in the population worldwide. Factors such as overweight and the reduced fluid intake in half the sample of lithiasic seem to be involved with the elevated observed calculi prevalence. Making water available, promoting continued education, monitoring the worker according to environmental and nutritional needs and controlling preventive actions must be measures that should be taken by managers in the public and private sectors, as a means to reduce the number o lithiasis among civil construction workers that, undoubtedly, are less expensive for SUS than tat of treatment. The data here reported serves as an indicator of public health managers and entrepreneurs so that together they may attempt actions to prevent lithiasis in workers acting in the civil construction industry, avoiding interventions by VISAT. It is hoped that such indicators will be disseminated among health managers, personnel managers, fiscal agents from VISAT, worker protection policy thinkers and employers, under which remains the great responsibility regarding the safety and sanity of workers. To prove the phenomena observed by this study on a greater scale, one needs more controlled work environments, a better-defined and previously calculated sample (based on the estimated prevalence identified in this study), great observation times, diagnostic examinations, along other refinement mechanisms.

Once capacitation and in-company workshops (about the promotion of workers health) is 
one of the pillars of VISAT, this joint action could take place with partnerships in the private sector, establishing parameters to protect workers health in the workplace and process. Such partnership, in the capacitation of workers, should be the focus of civil construction managers in the orientation and education of employees, in order to minimize the risks of renal lithiasis. Furthermore, companies should assume their parcel of social responsibility, supplying water freely and ad libitum, allowing for a greater number of pauses during working time and investing in the follow-up on diets oriented by nutritionists, avoiding the health impact that urinary calculi may generate in this group of workers.

\section{Collaborations}

RRN Ferraz and S Aquino participated equally in all stages of preparation of the article. 


\section{References}

1. Moreira M, Bernardes S. Planejamento e Controle da Produção para Empresas de Construção Civil. São Paulo: LTC; 2003.

2. Barbosa LA, Ramos W. Importância da prevenção de acidentes no setor de construção civil: um estudo de caso em Uberlândia, Minas Gerais, Brasil. Conhecimento Online [Internet]. 2012; 4(2). [cited 2013 Ago 16]. Available from: http://www.feevale.br/revistaconhecimento online

3. Brant LC, Minayo-Gomez C. A transformação do sofrimento em adoecimento: do nascimento da clínica à psicodinâmica do trabalho. Cien Saude Colet 2004; 9(1):213-223.

4. Tenaglia M. Construção civil e alcoolismo: um estudo de caso realizado em empresa da construção civil de Belo Horizonte [dissertação]. Belo Horizonte: Universidade Federal de Minas Gerais; 2004.

5. Lima MEA. Drug addiction and work: functional and disfunctional drug usage in labor contexts. Rev. Brasileira de Saúde Ocupacional 2010; 35(122):260-268.

6. De Mello ED, de Oliveira Schneider MA. A importância da dieta no manejo da hipercalciúria. Rev. Hospital de Clínicas de Porto Alegre e Faculdade de Medicina da Universidade Federal do Rio Grande do Sul 2006; 26:52.

7. Noto AR, Galduróz JCF. O uso de drogas psicotrópicas e a prevenção no Brasil. Cien Saude Colet 1999; 4(1):145-151.

8. Dias JC. Programas de atenção ao tabagismo e ao uso indevido de álcool e outras drogas no local de trabalho: Um investimento vantajoso. Rev Bras Med Trab 2005; 3(1):58-63.

9. Klausmeyer M. O peão e o acidente de trabalho na construção civil do Rio de Janeiro. Rio de Janeiro: Fundação Getúlio Vargas; 1988.

10. Sato L, Bernardo MH. Saúde mental e trabalho: os problemas que persistem. Cien Saude Colet 2005; 10(4):869-878.

11. Rocha PF. Avaliando o nivel de conhecimento dos trabalhadores da construção civil em relação a sua saúde ocupacional [dissertação]. Florianópolis: Universidade Estadual de Santa Catarina; 1998.

12. Brasil. Ministério da Saúde. Portaria $n^{\circ} 3.120$, de $1^{\circ}$ de julho de 1998. Aprova a Instrução Normativa de Vigilância em Saúde do Trabalhador no SUS. Diário Oficial da União 1998; 2 jul.

13. Driscoll T, Takala J, Steenland K, Corvalan C, Fingerhut M. Review of estimates of the global burden of injury and illness due to occupational exposures. Am J Ind Med 2005; 48(6):491-502.

14. Oliveira CAF, Espírito-Santo JS, Araújo G. Gravidade dos acidentes de trabalho atendidos em serviços de emergência. Rev Saude Publica 2009; 43(5):750-760.

15. Brasil. Portal da saúde. Saúde Brasil 2008. Vinte anos de sistema único de saúde (SUS) no Brasil. [Internet]. 2009 [cited $2013 \mathrm{Feb} 25$ ]. Available from: http://portal.saude. gov.br/portal/saude/Gestor/area.cfm?id_area=1499

16. Norlin A, Lindell B, Granberg PO, Lindvall N. Urolithiasis: A study of its frequency. Scand J Urol Nephrol 1976; 10(2):150-153.

17. Stamatelou KK, Francis ME, Jones CA, Nyberg LM, Curhan GC. Time trends in reported prevalence of kidney stones in the United States: 1976-1994. Kidney Int 2003; 63(5):1817-1823.
18. Strohmaier WL. Socioeconomic aspects of urinary calculi and metaphylaxis of urinary calculi. Urologe A 2000; 39(2):166-170.

19. Kambal A, Wahab EM, Khattab AH. Urolithiasis in Sudan. Geographical distribution and the influence of climate. Trop Geogr Med 1979; 31(1):75-79.

20. Prince CL, Scardino PL, Wolan CT. The effect of temperature, humidity and dehydration on the formation of renal calculi. J Urol 1956; 75(2):209.

21. Rieu P. Infective lithiasis. Ann Urol (Paris) 2005; 39(1):16-29.

22. Taylor EN, Stampfer MJ, Curhan GC. Dietary factors and the risk of incident kidney stones in men: new insights after 14 years of follow-up. J Am Soc Nephrol 2004; 15(12):3225-3232.

23. Borghi L, Meschi T, Amato F, Briganti A, Novarini A, Giannini A. Urinary volume, water and recurrences in idiopathic calcium nephrolithiasis: a 5-year randomized prospective study. J Urol 1996; 155(3):839-843.

24. Borghi L, Meschi T, Schianchi T, Briganti A, Guerra A, Allegri F, Novarini A. Urine volume: stone risk factor and preventive measure. Nephron 1999; 81(1):31-37.

25. Heilberg IP. Update on dietary recommendations and medical treatment of renal stone disease. Nephrol Dial Transplant 2000; 15(1):117-123.

26. Weiss GHJ, Sluss PM, Linke CA. Changes in urinary magnesium citrate, and oxalate levels due to cola consumption. Urology 1992; 39(4):331-333.

27. Odvina CV. Comparative value of orange juice versus lemonade in reducing stone-forming risk. Clin J Am Soc Nephrol 2006; 1(6):1269-1274.

28. Brasil. Ministério da Saúde (MS). Conselho Nacional de Saúde. Resolução no 196 de 10 de outubro de 1996. Diretrizes e Normas Regulamentadoras de Pesquisas Envolvendo Seres Humanos. Diário Oficial da União 1996; 16 out.

29. Associação Brasileira para o Estudo da Obesidade (ABESO) - 2013. [cited 2013 Aug 16]. Available from: http://www.abeso.org.br/

30. Street A. Gallstone disease: the cost of treatment. Revised version. Melbourne: Centre for Health Program Evaluation; 1993. Working paper 29.

31. Cook J, Richardson J, Street A. Cost Utility Analysis of Treatment Options for Gallstone Disease: Final Report. Melbourne: Center for Health Program Evaluation; 1994. Working paper 35.

32. Costa PS, Silva CAT. Análise do impacto do progresso tecnológico nos custos do tratamento hospitalar: o caso do tratamento para litíase urinária no Hospital Universitário de Brasília. Cadernos EBAPEBR 2006; 29(1):1-15.

33. Brasil. Ministério da Saúde (MS). Portaria ${ }^{\circ} 1.823$, de 23 de agosto de 2012. Institui a Política Nacional de Saúde do Trabalhador e da Trabalhadora. Diário Oficial da União 2012; 24 ago.

Article submitted on $06 / 09 / 2013$

Approved 25/09/2013

Final version submitted on 30/09/2013

Translated by 